\title{
STUDY ON GEOGRAPHY STUDENTS' INTERNET USE
}

\author{
MARIA ELIZA DULAMĂ \\ Babeş-Bolyai University, Faculty of Psychology and Sciences of Education, Cluj-Napoca, Romania, \\ e-mail: dulama@upcmail.ro
}

IOANA MAGDAŞ

Babeş-Bolyai University, Faculty of Psychology and Sciences of Education, Cluj-Napoca, Romania, e-mail: magdas_ioana@yahoo.com

\section{GABRIELA OSACI-COSTACHE}

University of Bucharest, Faculty of Geography, Bucharest, Romania, e-mail: gabrielaosaci68@yahoo.com

(Received: February 2015; in revised form: February 2015)

\begin{abstract}
In this study we analyze the behavior of a sample of 30 third-year students of various majors of the Faculty of Geography, "Babeş-Bolyai" University of ClujNapoca, Romania, regarding the Internet use. We applied a questionnaire containing 15 items related to: Internet activities performed; length of time students spend on the Internet; devices used to access the Internet; types of materials that students downloaded, read, viewed, forwarded or posted on the Internet; types of applications used. Taking into account the time students spent daily on the Internet and correlated with other responses we concluded that their concerns were closely related to the Internet, whether it was about communication, career, or personal life.
\end{abstract}

Keywords: Facebook, social networks, website, e-learning, on-line 


\section{INTRODUCTION}

Currently Geography benefits by the development of the Web 2.0 "phenomenon", which is bi-directional, allowing users both viewing sites' content and interaction (Goodchild, 2007; Giannola, 2013). Some Geography students said that they usually spend 4-5 hours daily on the internet. They are active on Facebook social network where there can be visible some materials posted or forwarded by them, their topics of interest (personal or professional), thematic debates that involve the values they promote.

Locally, we found that some students and teachers, along with members of NGOs (Non Governmental Organizations) and other citizens of Cluj-Napoca expressed their views and have mobilized themselves through the social networks to manifest against Roșia Montană gold exploitation: "Viral on Facebook is a poster calling for a Roșia Montană rally and march on Sunday, September 8, 2013, starting at 17.00, in Union Square in ClujNapoca" (http://www.napocanews.ro/2013/09/nou-miting-duminica-pentrurosia-montana-la-cluj-napoca.html). Similar protests were held against the exploitation of shale gas by fracking in Romania (http://www.ziare.com/clujnapoca/articole/ protest+impotriva+exploatarii+g azelor+de+sist), managing to temporarily block these exploitations, as well. Facebook social network had a decisive role in mobilizing citizens of ClujNapoca city, including students at marches and peaceful demonstrations in markets, before the presidential elections in November 2014 (http://adevarul.ro/news/eveniment/mii-romani-ies-strada-semnsolidaritate-diaspora-indemna-oamenii-iasa-vot-

1_5465f6fe0d133766a8db8cdl/index.html). "The second round of presidential elections is the first election in Romania in which a social network was recognized as having major impact on a local political event" (http://economie.hotnews.ro/stiri-media_publicitate-18598966-analizahotnews-cum-functionat-partidul-facebook-ziua-victoriei-lui-iohannis. htm). After this event the social network Facebook was named "Facebook Party" in Romania (Ibidem).

In the context of Web 2.0, each student "can gain access to information by vocation, needs, pace and learning style etc." (OsaciCostache et al., 2014, p. 219). Accessing information in online informal activities provides learning opportunities for students of which they are unaware (De Pietro et al., 2013, p. 115). "The wide dissemination and the easy way in which the maps with mistakes can be obtained from the virtual environment makes it potentially dangerous" (Osaci-Costache, 2012, p. 126; Osaci-Costache et al., 2014, p. 219). Since some information that circulate in the online environment are incorrect, it is necessary to train the students, under teacher guidance, as "reflective students" (Cinque, 2013), through a formal student-centered education, in which the students and 
their formative needs are in the center of the learning process (De Pietro et al., 2013 , p. 128). Beyond informing students, the teacher's role is to form them, having also the duty to verify the information and do what the Internet does not: to teach students how to "search, filter, select, accept or refuse such information" found on the Internet (Eco, 2007). E-learning 2.0 thus leads to the fusion between formal and informal (De Pietro et al., 2013, p. 128).

Recognizing the impact that generally the Internet and particularly the Facebook network have, in promoting ideas and mobilizing large masses of people, we asked ourselves: How could we exploit the information and communication virtual environments in higher education to increase the effectiveness of learning, training and developing specific skills of Geography and of Geography teacher? In this context, the objective of this exploratory research is to know and analyze student behavior on using the Internet in formal and informal activities. The results of this research will be useful to us in rethinking learning activities at the university level.

\section{METHOD}

a. Participants. This research aimed to analyze the behavior of a sample of 30 third-year students from various majors (Geography, Geography of Tourism, Hydrology, Meteorology, and Cartography) from the Faculty of Geography, "Babeş-Bolyai" University of Cluj-Napoca, Romania, in the academic year of 2014-2015. The sample size does not correspond to the total population of students who have completed courses and seminars of Didactics of Geography and Computer Assisted Instruction in the psychopedagogical module to become teachers of Geography. The different levels of knowledge and skills of the variable subject influenced the quantitative results of the research. Being a limited study for one college and for a limited sample size, these may influence data generalization.

b. Data collection. For data collection, we applied a questionnaire made on Google Forms from Google Drive. The questionnaire was sent by e-mail to 45 students undergoing Psycho-Pedagogical Module out of whom 30 students have voluntarily responded. The questionnaire was anonymous, so we could not correlate the answers with the students' names. The questionnaire contains 15 items. First question (see Figure 1) asked to score between 1 and 5 points for each statement in a list according to the level that activity represented from the total of their activities on the Internet ( 1 - I have no such activities, 2- I have few such activities, 3 - I have an average amount of such activities, 4 - I have many such activities, 5 - I have very many such activities). Twelve items (see figures 2 to12) had multiple-choice answers that allowed for more choices from a list. On two items, students were asked to write the pages with geographical 
content they appreciated and followed on Facebook and existing groups on Facebook that aim Geography and in which they were enrolled.

\section{RESULTS AND DISCUSSION}

First question has been asked in order to identify the categories of activities in which students engaged on the Internet and to determine the quantity of activities in each category. Next, we analyzed and interpreted these activities, represented in Figure 1 . We could see that over $75 \%$ of students used the Internet much or very much for information/documentation/viewing/games for personal purposes (hobbies, sports, etc.) while $10 \%$ of them used the Internet little or not at all. We note that all students use the Internet for information/documentation/viewing/games for professional/learning purposes activities. Thus $83 \%$ of the students use the Internet much and very much and only $17 \%$ use it at an average level.

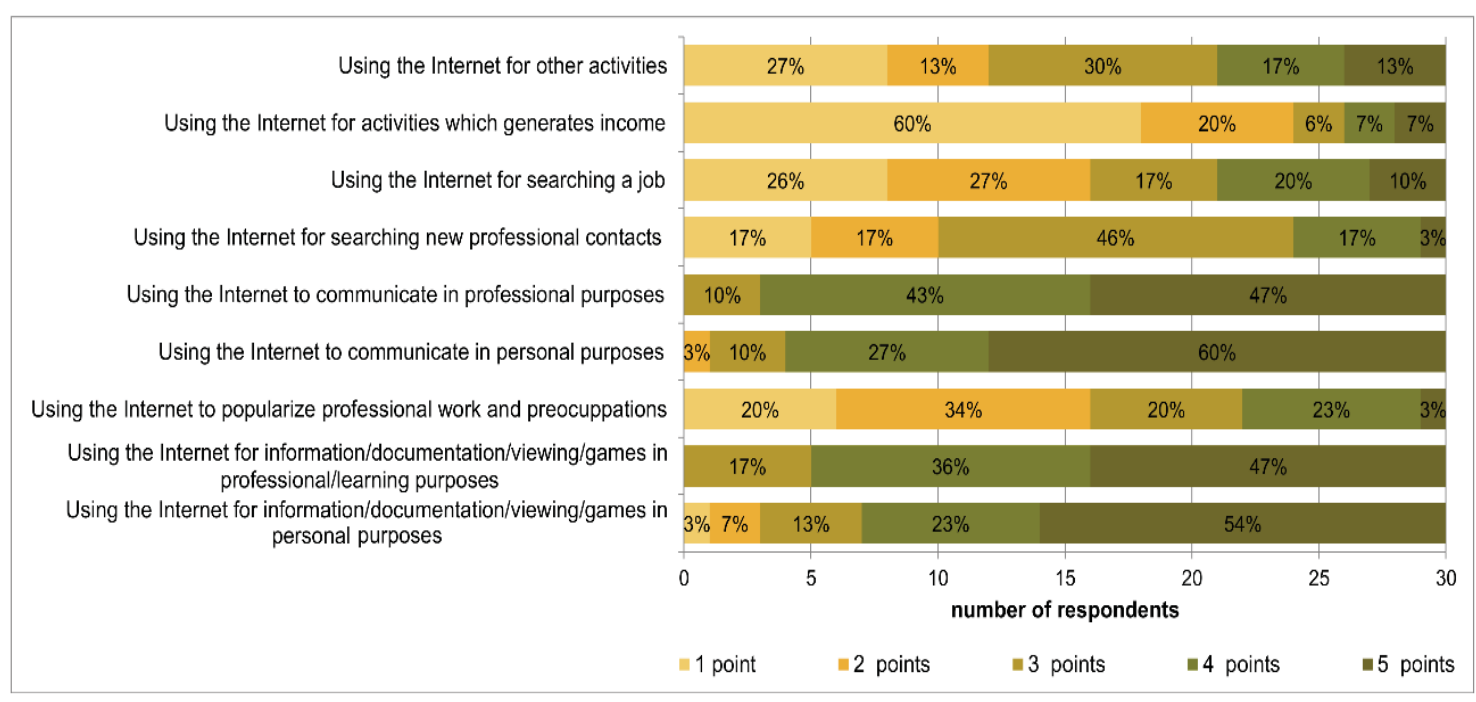

Fig. 1. Internet activities performed by students

It shows that only $3 \%$ of students use much the Internet to popularize their professional work and interests, while $43 \%$ of them use it much and at an average level. The fact that $54 \%$ of students use the Internet little or not at all for this purpose can be explained by the fact they do not perform paid work and do not consider their professional activities necessary to be promoted on the Internet. Unfortunately, students are less involved in scientific research, they rarely participate in symposia, such as Geography Youth Symposium (http://egeacluj. blogspot.ro/2012/05/cum-fost-la-simpozionul-tinerilor.html) (First Edition: 19 - 20 of May 2012; second edition: 17 - 18 of May 2013 in 
Cluj-Napoca) organized by the EGEA Cluj-Napoca (European Geography Association). From this perspective, even if students have other professional interests (e.g. performing teaching practice, Geography field trips), they do not promote them in the virtual environment.

It is remarkable that $97 \%$ of the surveyed students use the Internet above average for communication for personal purposes, perhaps because of the high costs of using other communication channels (mail, phone). We appreciate the all the surveyed students used the Internet very much and much to communicate with peers and teachers for professional purposes, showing a fast readjustment to new technologies. Even students attending full time courses use these channels to receive information from teachers and peers about exams and tasks. They perform many tasks electronically and send them to teachers via e-mail. In the case of Psycho-Pedagogical Module, students were encouraged to ask questions via email.

Geography students are little (17\% of them) or not at all (17\% of them) concerned with searching new professional contacts by using the Internet. Only $20 \%$ of surveyed students use much or very much the Internet for this purpose, and $47 \%$ of them use it at an average level. These values can be explained by the fact that students are part of a larger learning community that provides the information necessary to develop professionally.

The fact that $53 \%$ of students use little or not at all the Internet for searching a job shows that they have financial sources for their education, while $47 \%$ of them use it for this purpose. A less interest was shown by $80 \%$ of students for the Internet activities that generate income. However, $40 \%$ of students use the Internet for activities that generate income, and a large number of students $(60 \%)$ use the Internet for activities other than those mentioned, but we do not have information about the nature of these activities.

Mobile devices (smartphone, pads, etc.) facilitate the access to online data at all time if there is Internet connection (Osaci-Costache et al., 2014, p. 218), promoting learning: "m-learning is the point at which mobile computing and e-learning intersect to produce an anytime, anywhere learning experience" (Harris, 2001 apud Cinque, 2013, p. 40). For this reason, we were interested in finding out how students use devices to access the Internet. In Figure 2, we see a very large share of using mobile phones and laptops to access the Internet. This preference is explained by the fact that these devices satisfy the request about price, size, performance and applications available (what you can do with them). A less use of computers located in college, tablets and personal computers for this purpose can be explained by size, price or access. These results also indicate that many students use multiple devices: $80 \%$ use both laptops and mobile phones while $20 \%$ of them use three kinds of mobile devices (laptop, tablet, mobile phone), and 16, 66\% use both fixed and mobile devices (personal computer, laptop, mobile phone). 


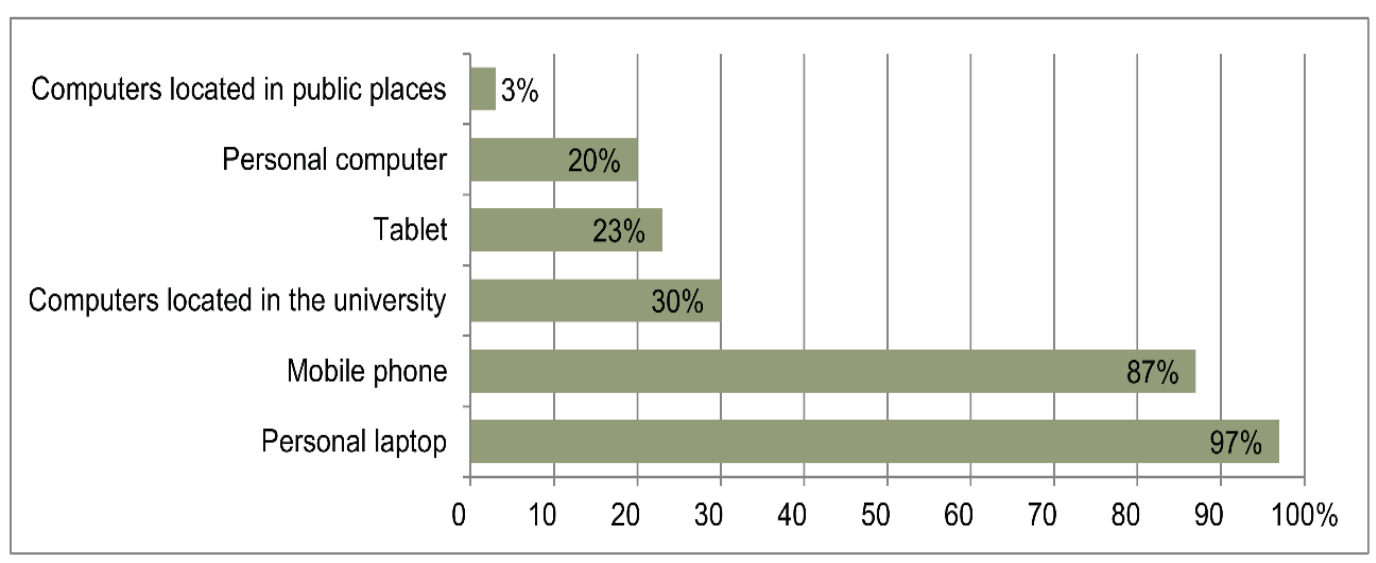

Fig. 2. Devices used by students to access the Internet

We were interested in the type of specialized materials students download from the Internet. The downloading quantity of these materials shows their preferences for certain sources. In Figure 3, we notice that most students download geographical images, Geography documentaries, Geography e-Books and PowerPoint Geography presentations. The fact that Geography students prefer images and documentary films, against other materials is completely understandable because Geography researches the geographical space, and this can be studied as the "environment" of human society or any other component, abiotic, biotic, anthropogenic, considered subjectively as central "term" under investigation (Mac, 2000).

Much less students (37\%) download Geography educational softwares, Geography lesson projects, annual and unit plans for learning Geography. Students showed a little interest for downloading scientific articles and e-books for Geography Didactics. It is surprising that only $17 \%$ of students download animations of Geography, perhaps because they are less quantitative than other sources available on the Internet. Very few students declared they use the Internet to download other materials related to their specialization, but we do not know what kind of materials. Our results indicate that students download several types of materials. Through the applied questionnaire we did not investigate the sources from where they downloaded materials.

We were also interested what Internet materials students watch for documentation in their specialization. In Figure 4, it is shown that most of the students watch geographic images (93\%) and geographic documentaries $(87 \%)$. If in the case of images, the percentage of students that download them is higher than of those who watch, while in the case of documentary films, the situation is reversed. PowerPoint Geography presentations are ranked on the third place, since $60 \%$ of students watch and download them. Many Geography teachers in Romania upload presentations on the site www.didactic.ro. From discussions with students we know they elaborate various PowerPoint presentations as homework for different subjects and for teaching practice lessons. On the last places are: TV shows with geographic 
content $(33 \%)$, geographical animations $(23 \%)$, TV news programs $(17 \%)$. The percentage of students who use the Internet for watching TV shows with geographic content looks high, but it can be explained by the fact that many students live in campus and do not have TV access. It would be interesting to investigate which are the TV channels and news broadcasts preferred by geography students. We are surprised again by the small percentage of students who watch Geographical animations.

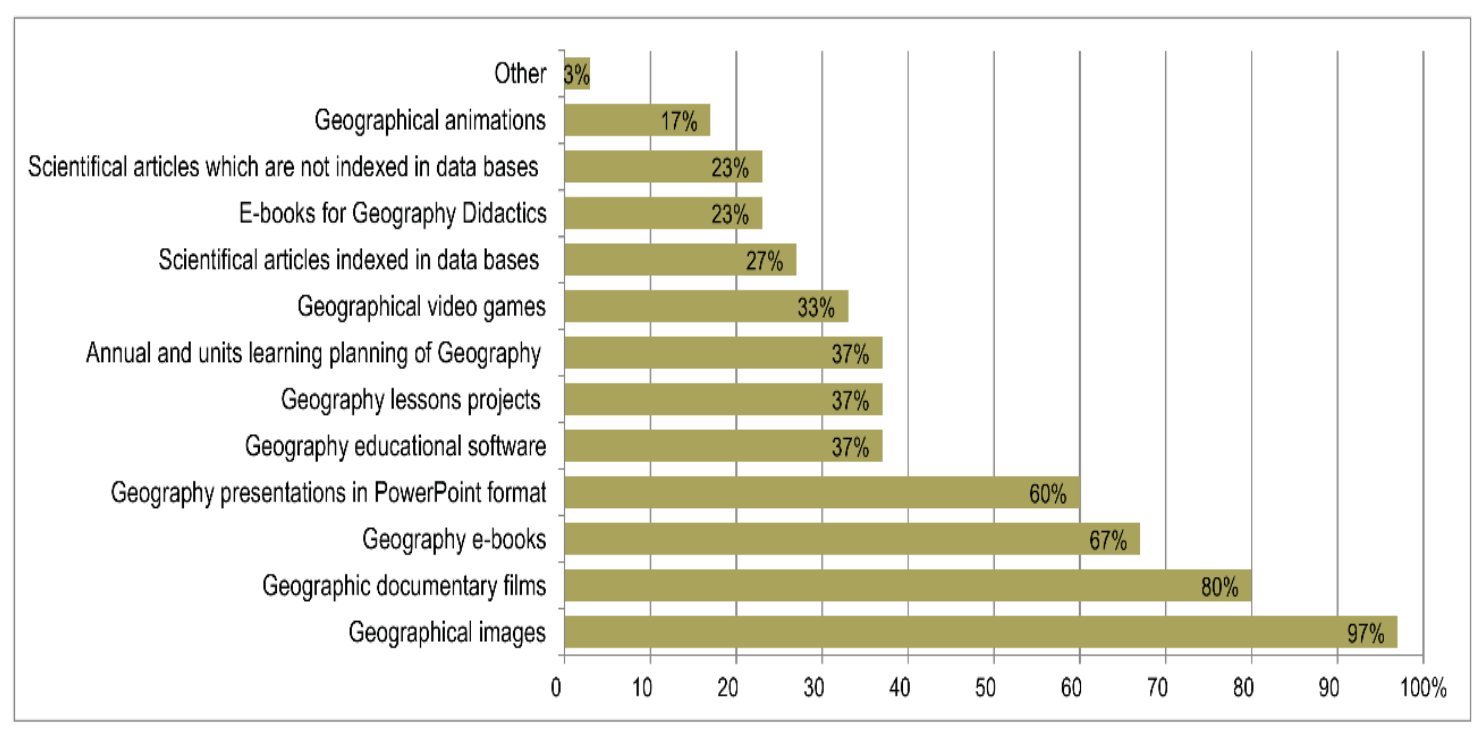

Fig. 3. Types of specialty materials students download from the Internet

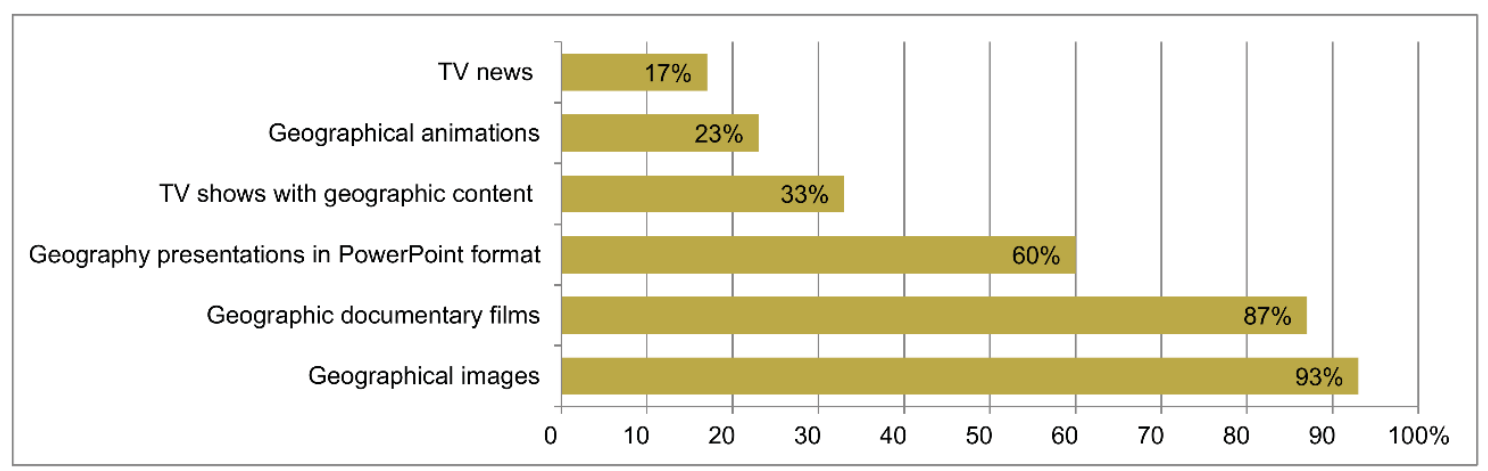

Fig. 4. Types of specialty Internet materials watched by students

We were interested in what Internet materials students read. Figure 5 shows that $67 \%$ of students use the Internet to read Geography e-books, an equal percentage with students who use the Internet to download such books. We deduce they download materials in order to have them permanently at disposal, and this is natural because they are easy to store 
and most often free of charge, while printed books are not free and more difficult to store and move. A smaller number of students download (23\%) and read (37\%) e-books of Geography Didactics. We note that very few free books in Romanian language in this field are posted on the Internet, e.g. Dulamă (2001), Mândrut (2011, 2012), Catană \& Mândruţ (2012), Mândruţ, Mândruţ \& Boboc (2012), Tomescu (2003). We note the high percentage of students $(53 \%)$ who use the Internet to read Geography lessons projects, which might be explained by the fact they have to develop projects to support their teaching practice lessons. For students, the Internet has been the most accessible source to find lessons projects, especially because there are only few collections of printed lesson projects (Dulamă, 2007, 2010; Dulamă \& Mihalca eds., 2010). We are surprised by the high percentage of students $(37 \%)$ who use the Internet to read Geography annual and unit learning planning. We explain this interest in that they seek information to develop projects for teaching practice lessons. The fact that $53 \%$ of students use the Internet to read lesson projects and only $37 \%$ to read lesson plans it is explained by the fact that mentors have made available their plans, so they do not need other resources. Students use the Internet to read non-indexed scientific articles (30\%) in a higher percentage than to read scientific articles indexed in international databases (17\%). There is no certainty that they know the difference and we believe these differences appeared because they responded randomly.

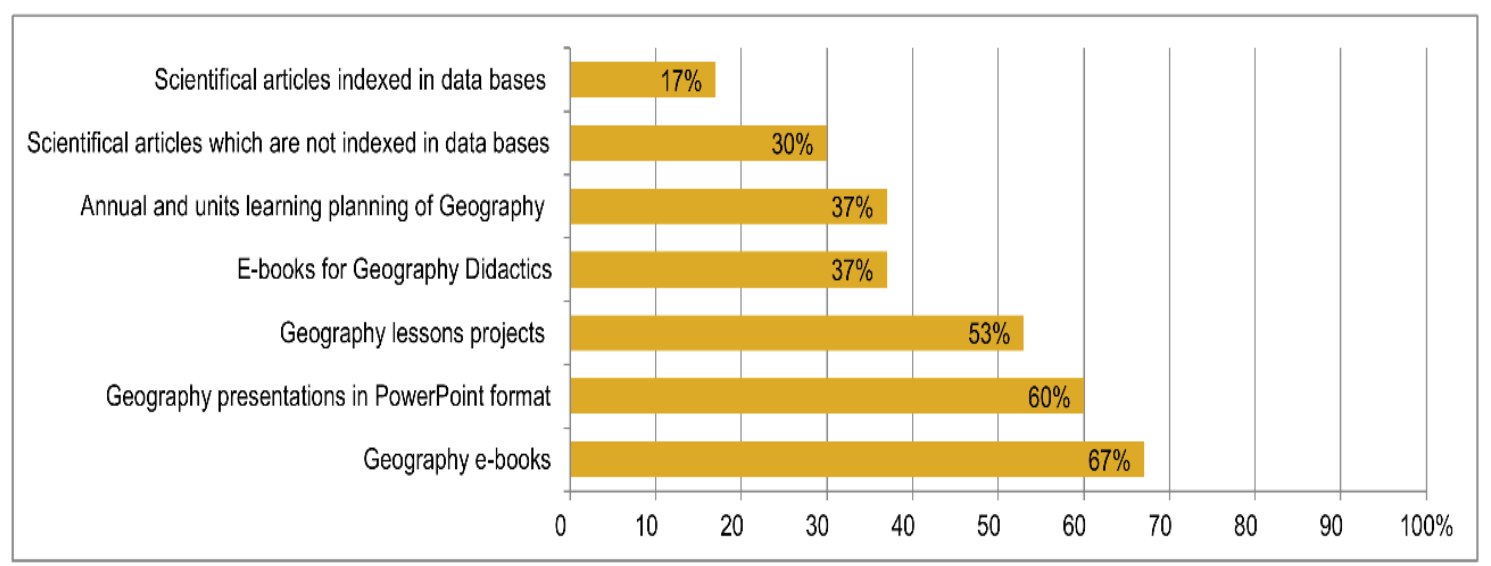

Fig. 5. Types of specialty Internet materials read by students

We were interested what materials created by students were related to their specialization are posted on the Internet. In Figure 6 we can notice that many of the surveyed students $(77 \%)$ used the Internet to post geographical images made by them. Surprisingly, $40 \%$ of students use the Internet to post their texts with geographical content, especially since we have no information about the content and quality of these texts, if the texts were posted on social networks or on Geography content websites. We also are surprised by the fact that $13 \%$ of students use the Internet to post Geography PowerPoint presentations and $10 \%$ of them post Geography 
lesson projects/plans. Many Geography teachers in Romania post on the website www.didactic.ro lesson projects, texts, plans, but we do not have any information if students post such materials. About $13 \%$ of students say they use the Internet to post other materials created by them which are related to their specialization, but we do not know to which category these materials belong. It is not surprising that students do not post scientific articles, especially considering their poor interest in scientific research, as evidenced above.

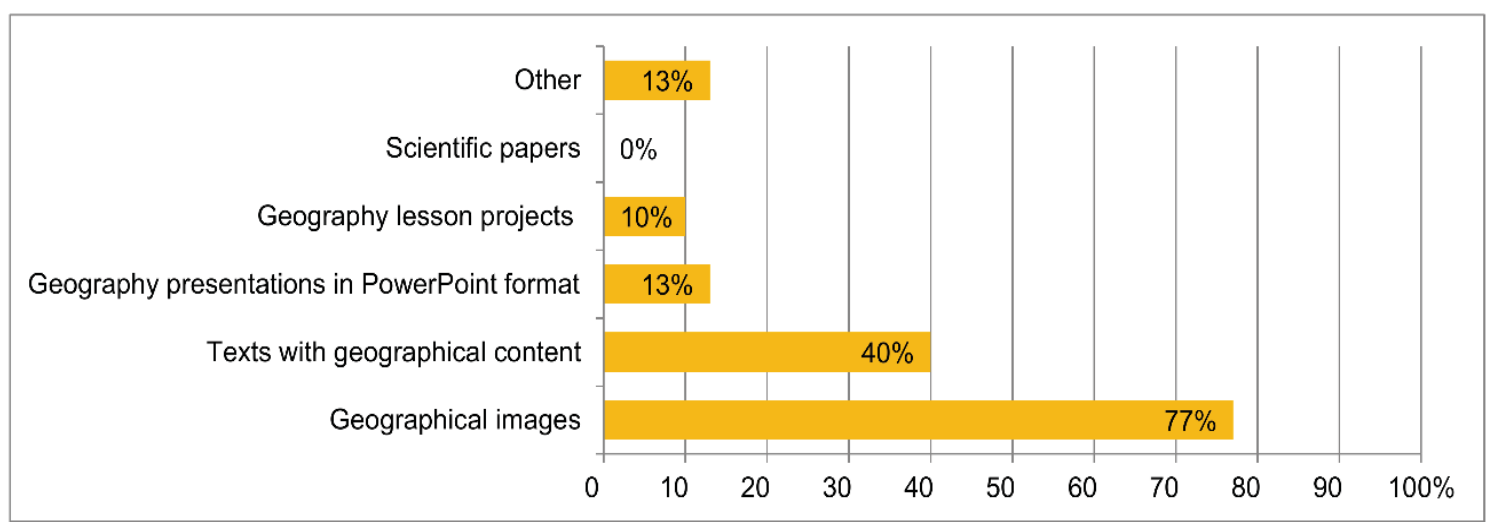

Fig. 6. Types of Internet posted materials created by students related to their specialization

We were interested in what materials students forward on Internet. Forwarded materials in electronic format are commonly used, especially on social networks where procedures are easy to apply. In Figure 7 we see that, most of the students $(87 \%)$ use the Internet to forward geographical images, but we expect all students to have done so. About $57 \%$ of students forward Geography sites, 50\% geographical documentaries, $43 \%$ Geography pages, 30\% Geography scientific articles and geographical animations. We note that these categories are heavily promoted and forwarded on social networks. Fewer materials forwarded by students are: PowerPoint Geography presentations (17\%), Geography lesson projects (10\%), Geography Didactics books (3\%), Geography Didactics scientific articles $(0 \%)$. On Facebook social network we did not identify PowerPoint presentations and lesson projects posted and forwarded. However, Geography Didactics books (e.g. Dulamă, 2001) have been posted and forwarded, but it seems the surveyed students do not have this information. In 2015, we promoted a page of books and scientific articles on Facebook, many of them with themes of Geography Didactics in Romanian and English, but it seems that students, even if they did see them, they have not yet studied and forwarded them. 


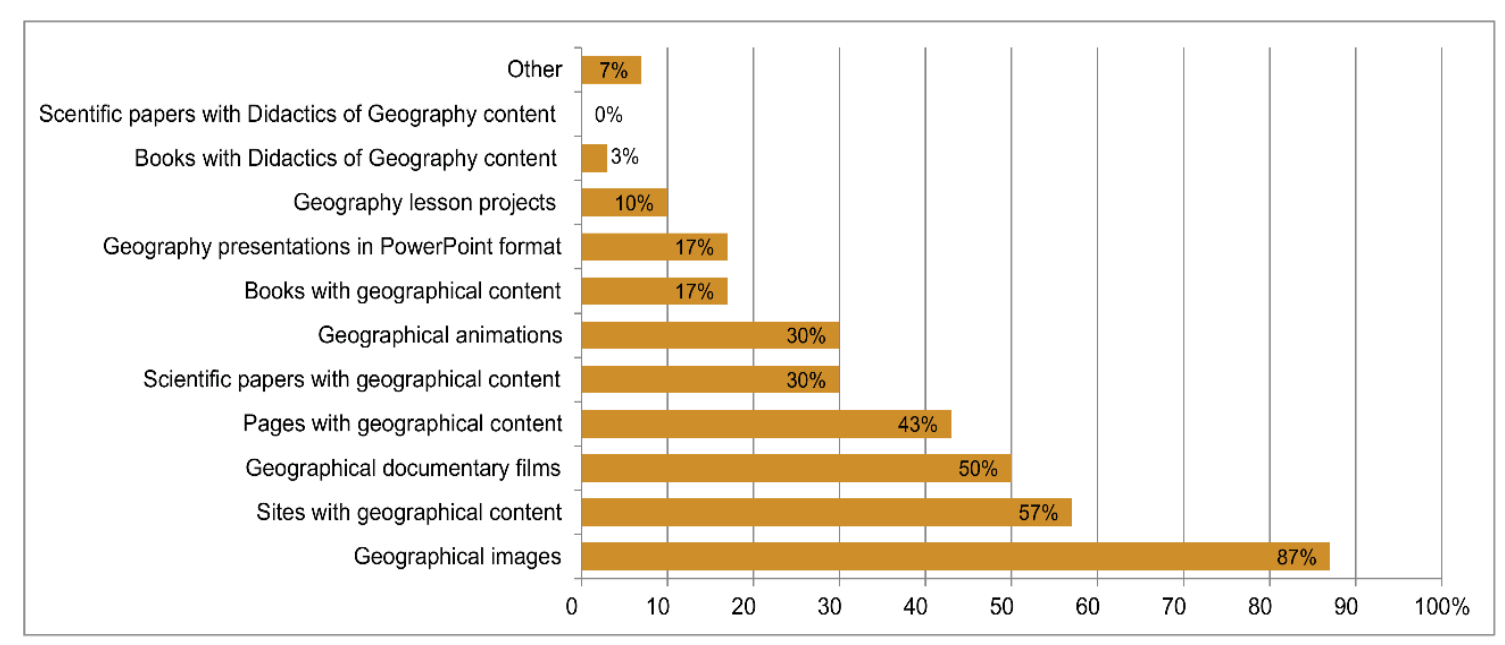

Fig. 7. Internet materials forwarded by students

We were interested in the communication ways used through the Internet. From figure 8 we observe that all students use the social network Facebook for communication on the Internet, while social network Twitter and professional network LinkedIn are less used by students, not being attractive for them. About $95 \%$ of students use e-mail for communication, but we should expect to be used by all of them. We were not surprised by the large share of the messenger communication $(60 \%)$, but by the large share of the communication through Skype (53\%). The fact that many students use the Internet for phone calls (50\%) and the WhatsApp application $(47 \%)$ indicate that they seek cheap solutions for voice communication and for this purpose they use current technologies. We also notice the students' lack of interest to communicate on forums (10\%), probably because they no longer fulfill their personal and professional interests and that are not a very effective way to find the information you need at a certain moment. From discussions with students, we found that they communicate a lot through discussion groups, created by students form each year of study. Each group has a student moderator who blocks inappropriate posts and discussions.

Considering the fact the Internet promotes information in various languages, we were interested in how much students benefit from them. In Figure 9 it is noted that all students have sought Geography information in Romanian, $87 \%$ in English and $20 \%$ in other languages. The large share of students looking for information in English may have a couple of explanations: students speak English, although is not compulsory because they can use Google translate; more information is posted in English on the Internet. The fact that $20 \%$ of students have looked for Geography information in other languages does not mean they know those languages, but they may have had other reasons. For example, we expect to find on the Internet relevant geographical information about a country (text, charts, and maps) in the official language of that country. Related to the previous 
question, we investigated whether students download information in other languages than their native language. In Figure 9 it is noted that all students have downloaded Geography information in Romanian from Internet. The percentage of students who downloaded information in English declined from $87 \%$ to $77 \%$, as compared to the percentage of those who sought information in Romanian. Also, the percentage of those who downloaded Geography information in other languages decreased from $20 \%$ to $13 \%$.

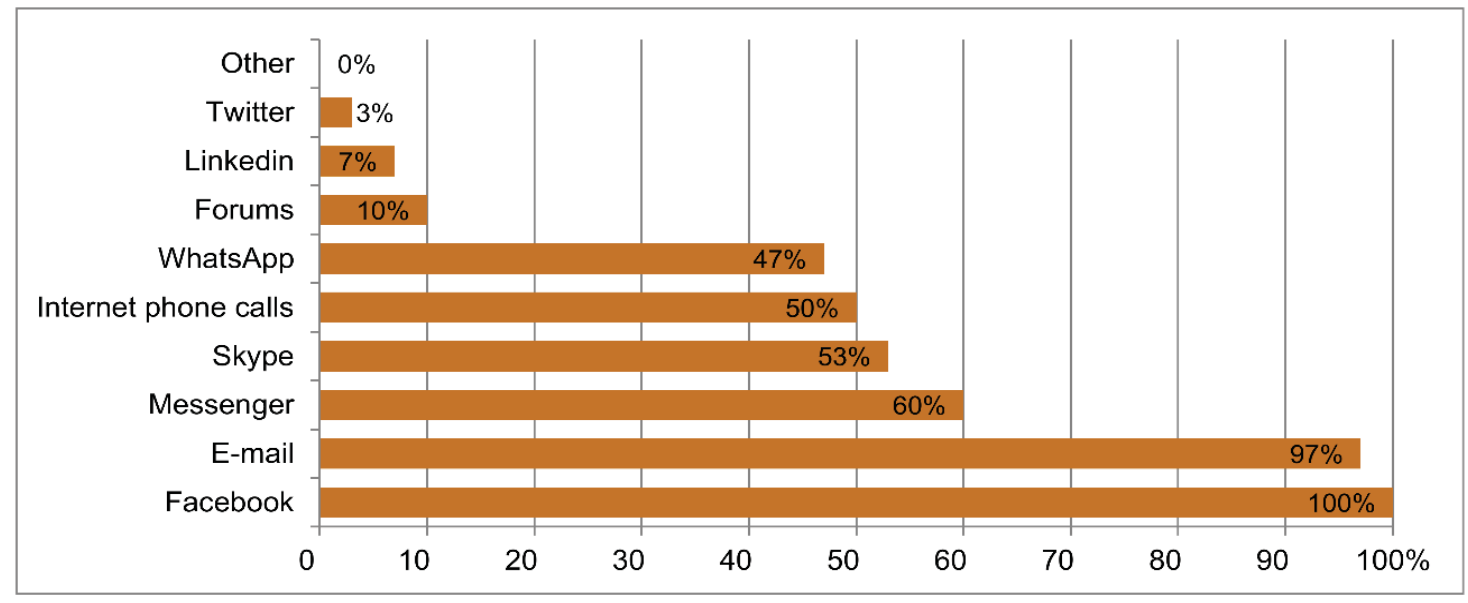

Fig. 8. Students' communication ways through the Internet

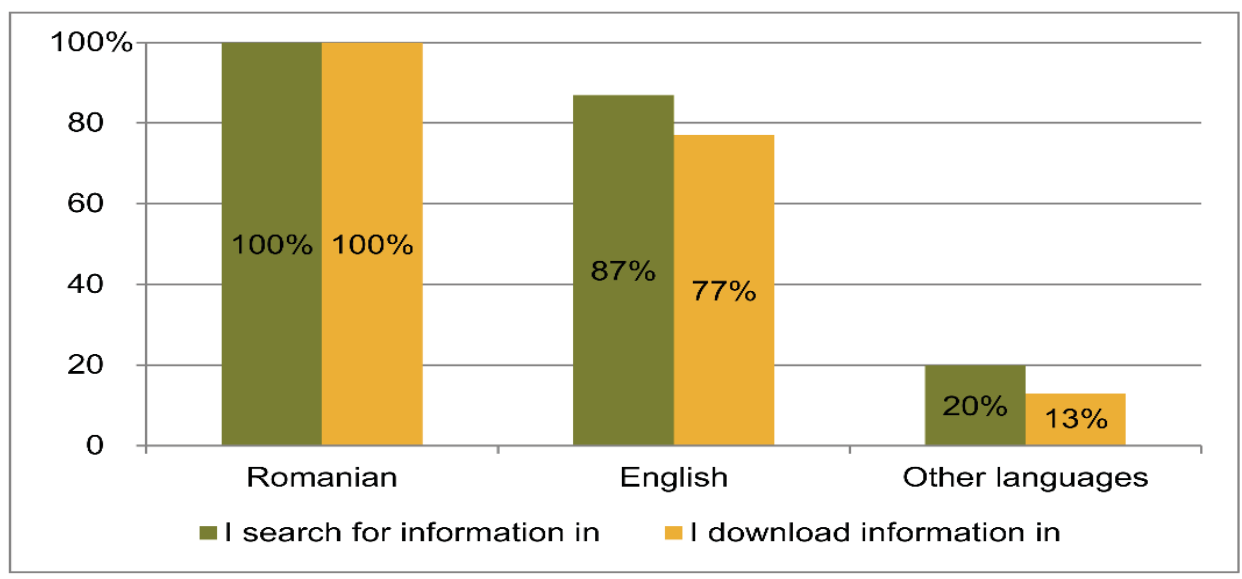

Fig. 9. Language of materials that students search and download

We also analyzed whether students seek information on the Internet independently or by someone's recommendation. In Figure 10 it is observed that $93 \%$ of students search by themselves information they need for their specialization. About $63 \%$ of students access pages recommended by others (colleagues, friends, family, teachers) for documentation in their specialization, while 33\% access pages promoted by the media. We expect 
all students to search for information both from their own initiative and also recommended by others, especially because much of such information is promoted by "friends" on Facebook.

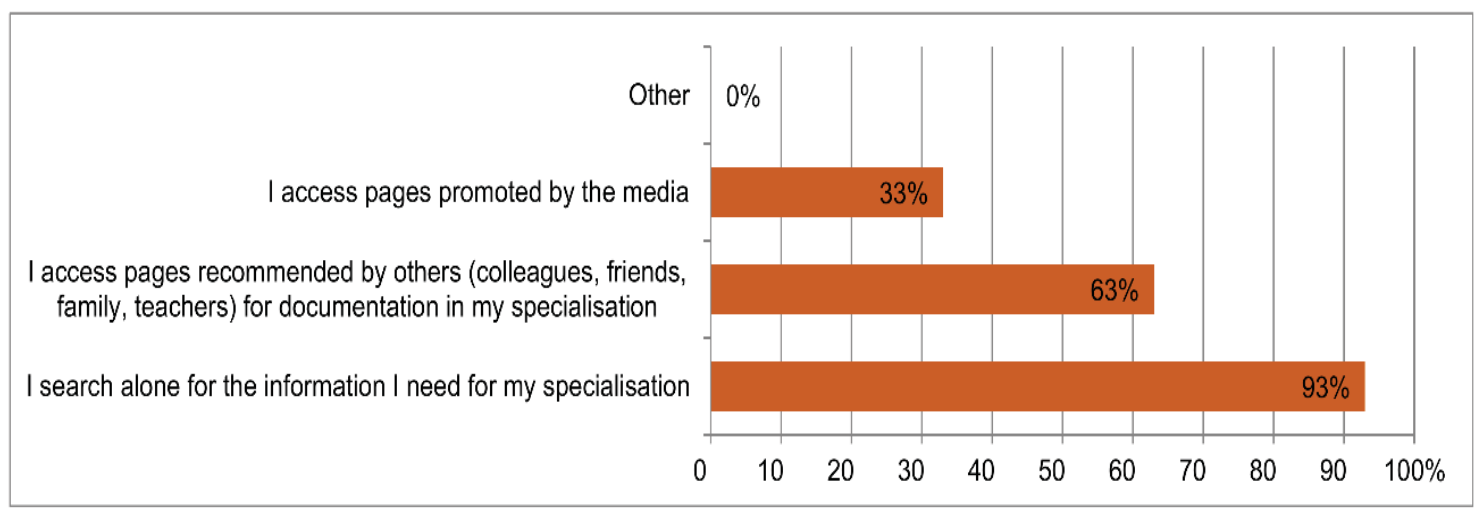

Fig. 10. Students' ways of searching information on the Internet

We investigated the ways in which students are active on Internet. In Figure 11 it is observed that all students have a Facebook account. Online space promotes the slogan: "If you're not on Facebook, you do not exist" (Bâtcă, 2011). What is surprising is that $23 \%$ of the students declared they had a Facebook page. About $97 \%$ of the students have e-mail accounts and all $97 \%$ said they use e-mail for communication. Four students $(13 \%)$ confirmed they have a Twitter account, but only one said that uses this network for communication. Two students stated they have a Linkedin account, and they also said they use this network for communication. Only one student said he has no personal blog or personal site.

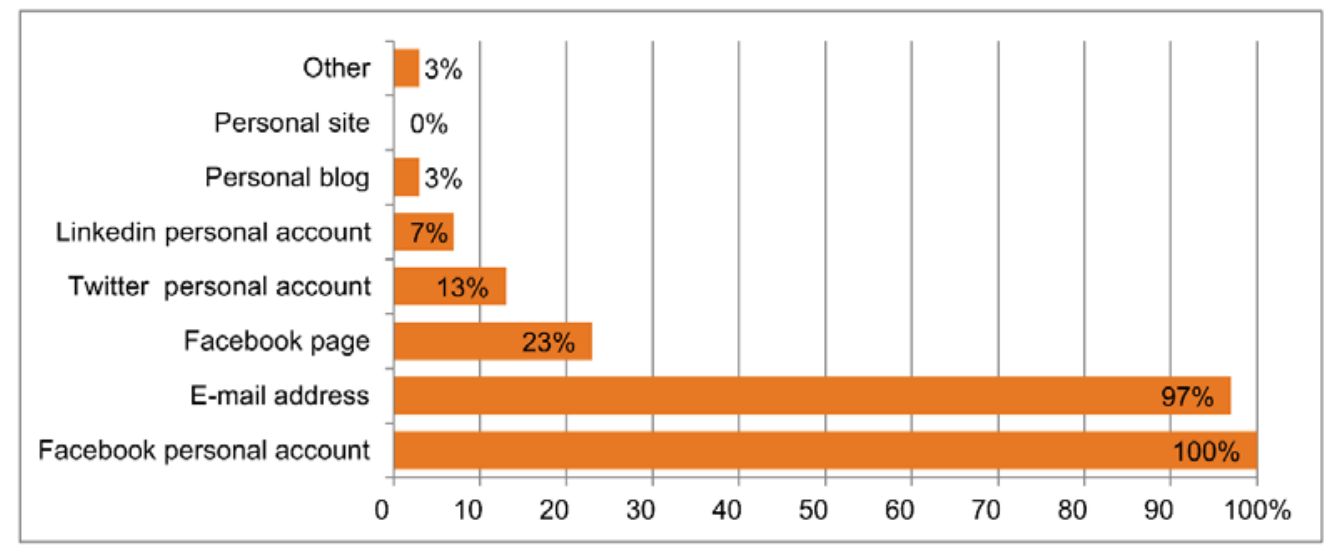

Fig. 11. Ways in which students are active on the Internet

In case of the item in which they are asked to nominate the Geography content pages they appreciate and watch on Facebook 27 students responded. Three students state they do not follow any pages, but 
we appreciate to be an implausible statement. The number of pages watched and exemplified by students range from 1 to 21: 1 page - 6 students; 2 pages - 4 students; 3 pages - 5 students; 5 pages - 3 students; 6 pages - 1 student; 9 pages - 2 students; 10 pages - 1 student; 11 pages - 1 student; 21 pages - 1 student. However, we believe these responses do not really reflect the reality because students watch many more pages, but it was difficult for them to label them in the questionnaire. One student said "I do not know exactly what I appreciate on Facebook, but generally all that there is about Geography, and especially, on Facebook, I like to read and if I appreciate then I like it and further distribute it". Another student does not specify the pages names, but he mentions their categories: "Air shootings of cities, geographical sites, monasteries, national parks and many other geographical places". The students mentioned the names of 42 different pages, out of which 31 names are in English and 11 in Romanian. On the other hand, 30 pages were followed by one student, 5 pages by 2 students, 2 pages by 3 students, 2 pages by 4 students (Tourist Guides, Geomorphology Rules), 2 pages by 5 students (Geography Climatology, Profu' de geogra' [The Geography teacher]), one page was tracked by 6 students (National Geographic). 27 students responded regarding public groups on Facebook that target Geography and in which students enrolled. Two students said that they are not enrolled in any groups and in any other group that aimed Geography. In each group 5 students were enrolled, 5 students were enrolled in 2 groups, 9 students in 3 groups, 3 students in 4 groups, 2 students in 5 groups. Students were enrolled in various groups: UBB Cluj-Napoca, Faculty of Geography (11 students), Geography Pedagogical Module ( 9 students), Geographers and teachers ( 6 students), EGEA Cluj-Napoca ( 3 students), GIS Romania (3 students). A number of 10 students were enrolled in discussion groups of specializations and years of study created on yahoo.com, not on extant Facebook public groups. Students mentioned the name of 6 groups in which only one of them was enrolled. One student mentioned an extant page on Facebook, instead of public groups. We were surprised that two students mentioned public groups that have an English name.

We were interested in the length of time students spend daily on the Internet. In Figure 12 we show that 34\% of students spend 4-6 hours daily on the Internet, $23 \%$ spend $2-4$ hours, $17 \%$ spend $6-8$ hours, $13 \%$ spend 1-2 hours, 3\% spend more than 8 hours, while 10\% chose the option "I don't know / No answer". These results confirm the claim that students spend 4-5 hours daily and even more on the Internet claim made by us at the beginning of research. None of students declared that spend less than an hour on the Internet. 


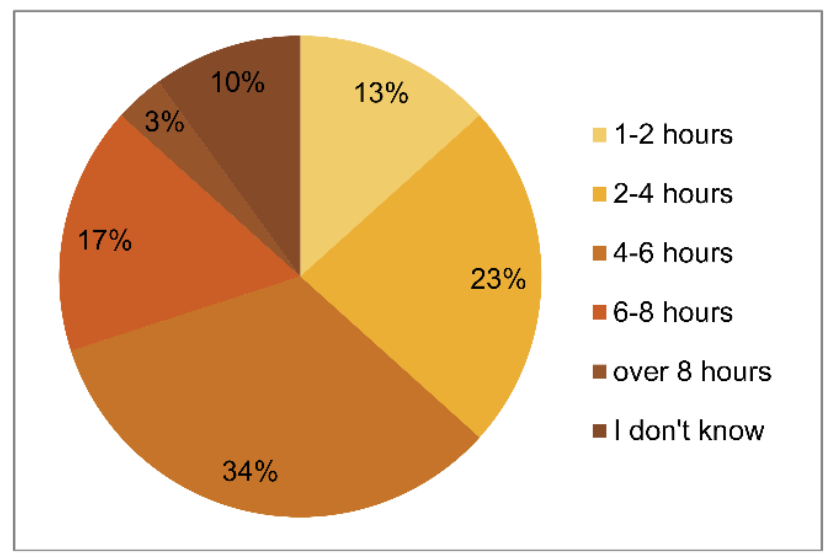

Fig. 12. The length of time students spend on the Internet

\section{CONCLUSIONS}

The research aimed to analyze the behavior of a sample of 30 third-year students from various majors (Geography, Geography of Tourism, Hydrology, Meteorology, and Cartography) from the Faculty of Geography, "Babeş-Bolyai" University of Cluj-Napoca, Romania, in the 2014-2015 academic year. We applied a questionnaire containing 15 items related to: their Internet activities; the length of time students spent on Internet; devices used to access the Internet; types of materials that students downloaded, read, viewed, forwarded or posted on the Internet; types of applications used.

Analyzing the participants' responses we found the following:

- most of the activities performed by students on Internet were for information/documentation/viewing/games for professional or for personal purposes, and for communication;

- $97 \%$ of students downloaded from and $93 \%$ of them watched geographical images on the Internet, these being the main types of materials they were interest in. Other interest materials were: Geography documentary films, books and PowerPoint presentations;

- regarding the types of Internet posted materials created by students and related to their specialization, geographical images had the first place with $77 \%$, while geographical texts represented $40 \%$ of posts;

- geographical images had the top position in terms of materials forwarded on the Internet;

- all students had a Facebook account and communicated using it, and $97 \%$ of them also used e-mails for communication; 
- students searched for information both in Romanian and in English, and $93 \%$ of them searched by themselves the Internet information they needed for their specialization; Internet.

- over $50 \%$ of students spent daily at least 4 hours daily on the

Taking into account the time students spent daily on the Internet and correlated with other responses we concluded that their concerns were closely related to the Internet, whether it was about communication, career, or personal life.

\section{References}

Ardelean, A., \& Mândruț, O. (coord.) (2012), Didactica formării competențelor. Cercetare, dezvoltare, inovare, formare. Arad: Universitatea de Vest „Vasile Goldiş", Centrul de Didactică şi Educaţie Permanentă. Retrieved February 2, 2015, from https://ro.scribd.com/doc/129529731/Didactica-CompetenteFinal

Bâtcă, A., Nu eşti pe Facebook, nu exişti. Cât va mai dura moda Facebook? Retrieved February 4, 2015, form http://www.evz.ro/nu-esti-pe-facebooknu-existi-cat-va-mai-dura-moda-facebook-932299.html

Cinque, M. (2013). "Lo studente riflessivo": I'uso di dispositivi mobili tra formazione on-the job e PLN (Personal Learning Network). Form@re - Open Journal per la formazione in rete, 11, 73, pp. 38-50. Retrieved February 6, 2015, from http:// www. fupress. net/index. php/formare/article/view/12554/11890

Cum a functionat "Partidul Facebook" in ziua victoriei lui Iohannis. Retrieved February 5, 2015, form http://economie.hotnews.ro/stiri-media_publicitate18598966-analiza-hotnews-cum-functionat-partidul-facebook-ziua-victorieilui-iohannis.htm

De Pietro, O., Muoio, P., \& De Rose, M. (2013). E-Learning 2.0: una ricerca sull'utilizzo di un Social Learning Environment in un contesto universitario. Topologik - Rivista Internazionale di Scienze Filosofiche, Pedagogiche e Sociali, 13, pp. 114-134. Retrieved February 6, 2015, form http://www.topologik.net/Orlando_De_Pietro_Pierluigi_Muoio_Maurizio_De_ Rose_Topologik_Issue_n.13_2013.pdf

Dulamă, M. E. (2001). Elemente de didactica geografiei. Cluj-Napoca: Editura Clusium. Retrieved February 1, 2015, from http:// www. didactic.ro/materiale-didactice/95296_elemente-din-didacticageografiei-de-dulama-maria-eliza-editura-clusium-cluj-napoca-2001-176-p

Dulamă, M. E. (2007). Geografie fizică. Planificări şi proiecte de lecţii pentru clasa a V-a. Cluj-Napoca: Editura Clusium.

Dulamă, M. E. (2007). Geografie fizică. Planificări şi proiecte de lecţii pentru clasa a V-a. Cluj-Napoca: Editura Clusium. 
Dulamă, M. E. (2010). Geografia populaţiei şi a aşezărilor, Proiecte de lecţii pt clasa a X-a. Cluj-Napoca: Editura Presa Universitară Clujeană.

Dulamă, M. E., \& Mihalca, I. A. (coord.) (2010). Europa, Proiecte de lecţii pt clasa a VI-a. Cluj-Napoca: Editura Presa Universitară Clujeană.

Eco, U. (2007). A che serve il professore? Retrieved February 6, 2015, form http://espresso. repubblica.it/opinioni/la-bustina-diminerva/2007/04/17/news/a-che-serve-il-professore- 1.3250

Giannola, E. (2013). II ruolo di Google Earth e OpenStreetMap nella partecipazione civica al processo decisionale. Bollettino dell'Associazione Italiana di Cartografia, 147, pp. 41-52.

Goodchild, M. F. (2007). Citizens as voluntary sensors: spatial data infrastructure in the world of Web 2.0. International Journal of Spatial Data Infrastructures Research 2, pp. 24-32.

Ilinca, N., Mândruț, O., Pârvu, C., Dan, S., Lazăr, N., \& Bărbulescu, A. (2011). Ghid de evaluare. Disciplina Geografie. In Potolea, D., Neacșu, I., \& Manolescu, M. (coord.), Proiectul: "Instrumente digitale de ameliorare a calităţii evaluării înînvăţământul preuniversitar". Retrieved February 3, 2015, from https://insam. softwin.ro/.../GHID\% 20DE\% 20EVAL_GEOGRAFIE2.pdf

Mac, I. (2000). Geografie generală. Cluj-Napoca: Editura Europontic.

Mândruț, O. (2011). Didactica geografiei I. Formare profesională a cadrelor didactice din învăţământul preuniversitar pentru noi oportunităţi de dezvoltare în carieră. Proiect cofinanţat din Fondul Social European prin Programul Operaţional Sectorial Dezvoltarea Resurselor Umane 2007-2013, București. Retrieved February 1, 2015, from http: // forum. portal. edu.ro/index. php?act=Attach\&type=post\&id=1994720

Mândruț, O. (2012). Didactica geografiei II. Formare profesională a cadrelor didactice din învăţământul preuniversitar pentru noi oportunităţi de dezvoltare în carieră. Proiect cofinanţat din Fondul Social European prin Programul Operaţional Sectorial Dezvoltarea Resurselor Umane 2007-2013, București. Retrieved February 1, 2015, from https://ro.scribd.com/doc/ 101226569/Didactica-geografiei-2

Mândruț, O. (2012). Instruirea centrată pe competenţe la geografie în învăţământul preuniversitar. Arad: Universitatea de Vest "Vasile Goldiş", Centrul de Didactică şi Educaţie Permanentă.

Mândruț, O., Catană, L., \& Mândruţ, M. (2012). Instruirea centrată pe competenţe. Arad: Universitatea de Vest "Vasile Goldiş", Centrul de Didactică şi Educaţie Permanentă. Retrieved February 2, 2015, from http:// www.slideshare. net/stelamirela/instruirea-centrata-pecompetente

Mândruț, M., Mândruț, O., \& Boboc, D. (2012). Didactica disciplinelor din învăţământul primar: Ştiinţele naturii şi Geografie. Arad: Universitatea de Vest "Vasile Goldiş", Centrul de Didactică şi Educaţie Permanentă. Retrieved February 2, 2015, from https://ro.scribd.com/doc/129529882/DidprimStGeo-Final

Nou miting duminică pentru Roşia Montana la Cluj-Napoca. Retrieved February 4, 2015, from http://www.napocanews.ro/2013/09/nou-miting-duminicapentru-rosia-montana-la-cluj-napoca.html

Osaci-Costache, G. (2012). La formazione delle competenze professionali nella 
specializzazione in Cartografia attraverso I'uso delle fonti cartografiche Web e dei programmi gratuiti, liberi e Open Source. Bollettino dell'Associazione Italiana di Cartografia, 144-145-146, pp. 123-135.

Osaci-Costache, G., Cocoș, O., \& Cocoș, A. (2014). Online Cartographic Materials for Geographical Higher Education: Opportunity or Threat?. In Vlada, M., Albeanu, G., \& Popovici, D. M. (eds.), Proceedings of the 9th International Conference on Virtual Learning ICVL 2014, Bucharest, 24-25 oct. 2014, Editura Universității din București, pp. 218-224.

Protest impotriva exploaterii gezelor de șist. Retrieved February 4, 2015, from http:// www.ziare.com/clujnapoca/articole/protest+impotriva+exploatarii+ga zelor+de+sist

Românii, în stradă înainte de alegeri. Retrieved February 5, 2015, form http://adevarul.ro/news/eveniment/mii-romani-ies-strada-semnsolidaritate-diaspora-indemna-oamenii-iasa-vot1_5465f6fe0d133766a8db8cd1/index.html

Talângă, C. (2007). Geografie și didactica geografiei. Formarea profesională a cadrelor didactice din învăţământul preuniversitar pentru noi oportunităţi de dezvoltare în carieră. Proiect cofinanţat din Fondul Social European prin Programul Operaţional Sectorial Dezvoltarea Resurselor Umane 2007-2013, București. Retrieved February 3, 2015, from http://tinread.usarb. md: 8888/tinread/fulltext/morari/geografie. pdf

Tomescu, V. (2003). Elemente de didactica geografiei. Craiova: Universitatea de la Craiova. Retrieved February 3, 2015, from https://ro.scribd.com/doc/101318913/Didactica-Geografiei-Viorica-Tomescu 